\title{
Identification of the natural ligand of Bet v 1
}

\author{
Christian Seutter von Loetzen*, Thomas Hoffmann, Maximilian Hartl, Kristian Schweimer, Wilfried Schwab, \\ Paul Rösch, Olivia Hartl-Spiegelhauer
}

From 5th International Symposium on Molecular Allergology (ISMA 2013)

Vienna, Austria. 6-7 December 2013

The major birch pollen allergen Bet $\mathrm{v} 1$ is the main elicitor of airborne type I allergies and belongs to the family 10 of pathogenesis related proteins. Bet $\mathrm{v} 1$ is the most extensively studied allergen and is well characterized on the biochemical and immunological level. However, its physiological function remained elusive. Here we present the identification of quercetin-3-O-sophoroside (Q3OS) as the natural ligand of Bet $\mathrm{v} 1$. We isolated Q3OS bound to Bet $\mathrm{v} 1$ from mature birch pollen and confirmed its binding by reconstitution of the Bet $\mathrm{v} 1$ :Q3OS complex. Fluorescence, UV/VIS as well as HSQC (heteronuclear single quantum coherence) titration experiments and the comparison with model compounds, such as quercetin, proved the specificity of Q3OS binding. The definition of the binding site by NMR together with a computational model give a more detailed understanding and shed light on the physiological function of Bet $\mathrm{v} 1$. We postulate that the binding of Q3OS plays an important but unexplored role during the inflammatory response and the Bet $\mathrm{v} 1$ recognition by IgE.

Published: 17 March 2014

doi:10.1186/2045-7022-4-S2-P3

Cite this article as: Seutter von Loetzen et al:: Identification of the natural ligand of Bet v 1. Clinical and Translational Allergy 2014 4(Suppl 2):P3.

Universität Bayreuth, Lehrstuhl für Biopolymere, Bayreuth, Germany

Submit your next manuscript to BioMed Central and take full advantage of:

- Convenient online submission

- Thorough peer review

- No space constraints or color figure charges

- Immediate publication on acceptance

- Inclusion in PubMed, CAS, Scopus and Google Scholar

- Research which is freely available for redistribution

Submit your manuscript at www.biomedcentral.com/submit
() Biomed Central

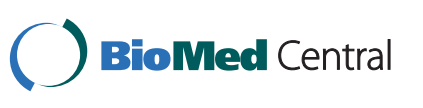

(c) 2014 Seutter von Loetzen et al; licensee BioMed Central Ltd. This is an Open Access article distributed under the terms of the Creative Commons Attribution License (http://creativecommons.org/licenses/by/2.0), which permits unrestricted use, distribution, and reproduction in any medium, provided the original work is properly cited. The Creative Commons Public Domain Dedication waiver (http://creativecommons.org/publicdomain/zero/1.0/) applies to the data made available in this article, unless otherwise stated. 